\title{
CORRECTION
}

\section{Correction to: High PD-L1 expression indicates poor prognosis of HIV- infected patients with non-small cell lung cancer}

\author{
Yusuke Okuma $^{1,2}$ (1) $\cdot$ Tsunekazu Hishima ${ }^{3} \cdot$ Jumpei Kashima $^{3} \cdot$ Sadamu Homma $^{1}$
}

Published online: 6 August 2018

๑) Springer-Verlag GmbH Germany, part of Springer Nature 2018

\section{Correction to:}

Cancer Immunology, Immunotherapy (2018) 67:495-505 https://doi.org/10.1007/s00262-017-2103-y

The graphs are incorrectly identified in Fig. 3i, s and should be replaced with the following:

Fig. 3i: PD-L1- NR; PD-L1 + 27.2 mos.

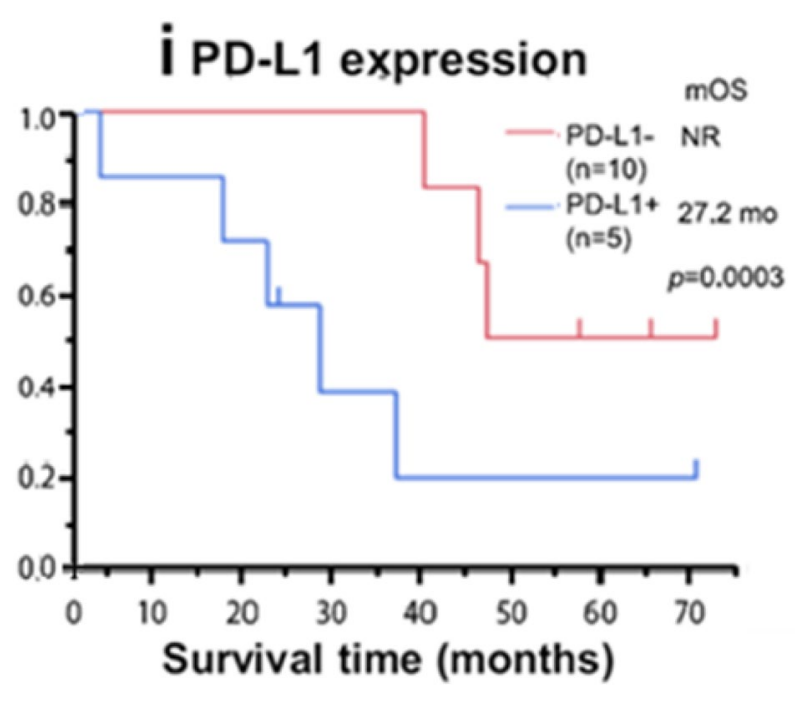

Fig. 3s: PD-L1-NR; PD-L1 + 21.3 mos.

\section{s. PD-L1 expression}

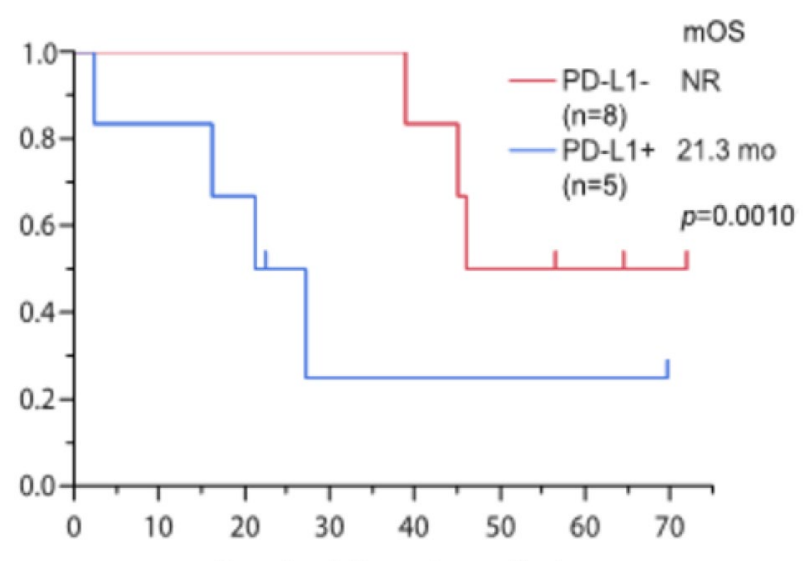

Survival time (months)
The original article can be found online at https://doi.org/10.1007/ s00262-017-2103-y.

Yusuke Okuma

y-okuma@cick.jp

Divison of Oncology, Research Center for Medical

Sciences, The Jikei University School of Medicine, 3-25-8

Nishi-shimbashi, Manato, Tokyo 105-8461, Japan

2 Department of Thoracic Oncology and Respiratory Medicine, Tokyo Metropolitan Cancer and Infectious diseases Center Komagome Hospital, 3-18-22 Honkomagome, Bunkyo, Tokyo 113-8677, Japan

3 Department of Pathology, Tokyo Metropolitan Cancer and Infectious diseases Center Komagome Hospital, 3-18-22 Honkomagome, Bunkyo, Tokyo 113-8677, Japan 
The previously published Table 2 includes the following error: The 2-year survival rate in an advanced stage in the propensity-score matched, non-HIV cohort $(n=13)$ was incorrectly identified as $35.7 \%$. The value is $50.0 \%$ as shown below.
2. In the " $n$ " column for "Non-HIV", the number for "PD-1 High" should be changed from " 3 " to " 2 ", and the number for "PD-1 Low" should be changed from " 26 " to " $27 "$ ".

\begin{tabular}{|c|c|c|c|c|c|c|c|c|}
\hline & \multirow{2}{*}{$\begin{array}{l}\text { HIV cohort } \\
(n=15)\end{array}$} & \multirow[t]{2}{*}{$\%$} & \multirow{2}{*}{$\begin{array}{l}\text { Non-HIV cohort } \\
(n=29)\end{array}$} & \multirow[t]{2}{*}{$\%$} & \multicolumn{4}{|c|}{ Propensity-score matched } \\
\hline & & & & & $\begin{array}{l}\text { HIV cohort } \\
(n=13)\end{array}$ & $\%$ & $\begin{array}{l}\text { Non-HIV cohort } \\
(n=13)\end{array}$ & $\%$ \\
\hline \multicolumn{9}{|c|}{ Cancer therapy in the initial setting } \\
\hline Surgery alone & 8 & 53.3 & 15 & 51.7 & 6 & 46.2 & 7 & 53.8 \\
\hline Radiotherapy alone & 1 & 6.7 & 1 & 3.4 & 1 & 7.7 & 0 & 0 \\
\hline $\begin{array}{l}\text { Chemoradiotherapy } \\
\text { (concurrent) }\end{array}$ & 2 & 13.3 & 4 & 13.8 & 2 & 15.4 & 4 & 30.8 \\
\hline Chemotherapy & 4 & 26.7 & 9 & 31.0 & 4 & 30.7 & 2 & 15.4 \\
\hline \multicolumn{9}{|l|}{ Survival time } \\
\hline $\begin{array}{l}\text { Patients in all stages } \\
(95 \% \mathrm{CI})\end{array}$ & $\begin{array}{r}45.1 \text { months } \\
(21.3-\mathrm{NR})\end{array}$ & & $\begin{array}{l}57.5 \text { months } \\
(21.4-102.6)\end{array}$ & & $\begin{array}{r}45.1 \text { months } \\
(21.3-\mathrm{NR})\end{array}$ & & $\begin{array}{l}102.6 \text { months } \\
(12.9-102.6)\end{array}$ & \\
\hline $\begin{array}{l}\text { Advanced stage (stage } \\
\text { IV) }(95 \% \text { CI) }\end{array}$ & $\begin{array}{r}21.3 \text { months } \\
(2.4-46.1)\end{array}$ & & $\begin{array}{l}21.4 \text { months } \\
(14.1-57.7)\end{array}$ & & $\begin{array}{r}21.3 \text { months } \\
(2.4-46.1)\end{array}$ & & $\begin{array}{l}21.4 \text { months } \\
(14.1-57.5)\end{array}$ & \\
\hline $\begin{array}{l}\text { 1-year survival rate in } \\
\text { advanced stages }\end{array}$ & $66.7 \%$ & & $100.0 \%$ & & $66.7 \%$ & & $100.0 \%$ & \\
\hline $\begin{array}{l}\text { 2-year survival rate in } \\
\text { advanced stages }\end{array}$ & $33.3 \%$ & & $35.7 \%$ & & $33.3 \%$ & & $50.0 \%$ & \\
\hline
\end{tabular}

The previously published Table 3 includes the following errors:

1. In the " $p$ value" column for "HIV", the third number was incorrectly labeled as " 0.039 " and should be replaced with " 0.39 ".
3. In the " $p$ value" column for "Non-HIV", the second number from the top was incorrectly labeled as "0.002", which, in fact, should be changed to " $0.02 *$ " (with an asterisk).

With the above mentioned corrections, the previously published Table 3 should be replaced with the following Table 3: 
Univariate analysis

\begin{tabular}{|c|c|c|c|c|c|c|}
\hline \multirow[t]{2}{*}{ Variants } & \multicolumn{3}{|c|}{ HIV } & \multicolumn{3}{|c|}{ Non-HIV } \\
\hline & $n$ & $\begin{array}{l}\text { Median OS (months) [95\% } \\
\mathrm{CI}]\end{array}$ & $p$ value & $n$ & $\begin{array}{l}\text { Median OS (months) [95\% } \\
\text { CI] }\end{array}$ & $p$ value \\
\hline \multicolumn{7}{|c|}{ Immunological status } \\
\hline \multicolumn{7}{|l|}{ PD-L1 } \\
\hline High & 5 & $27.2[2.4-27.2]$ & $0.0003 *$ & 8 & $57.5[20.5-\mathrm{NR}]$ & 0.80 \\
\hline Low & 10 & NR [35.8-NR] & & 21 & $64.3[3.4-102.6]$ & \\
\hline \multicolumn{7}{|l|}{ PD-1 } \\
\hline High & 2 & NR [2.4-NR] & 0.98 & 2 & $12.9[\mathrm{NR}]$ & $0.02 *$ \\
\hline Low & 13 & $45.1[35.8-\mathrm{NR}]$ & & 27 & 57.5 [21.4-102.6] & \\
\hline \multicolumn{7}{|l|}{ CD4 } \\
\hline High & 14 & $45.1[21.3-\mathrm{NR}]$ & 0.39 & 27 & NR [3.4-NR] & $0.023 *$ \\
\hline Low & 1 & $35.8[\mathrm{NR}]$ & & 2 & 57.5 [21.4-102.6] & \\
\hline \multicolumn{7}{|l|}{ CD8 } \\
\hline High & 15 & $45.1[21.3-\mathrm{NR}]$ & - & 26 & $57.5[3.4-57.5]$ & 0.25 \\
\hline Low & - & - & & 3 & 102.6 [21.4-102.6] & \\
\hline \multicolumn{7}{|l|}{ CD56 } \\
\hline High & 1 & $2.4[2.4-\mathrm{NR}]$ & $0.0002 *$ & 2 & NR [21.4-NR] & $0.002^{*}$ \\
\hline Low & 14 & $45.1[16.2-46.1]$ & & 27 & 21.4 [12.9-57.5] & \\
\hline
\end{tabular}

The following sentences in the text must be corrected:

In the "Results" section, the sentence on page 498 lines 16-18 is incorrect:

(Original) "Infiltration and accumulation of CD4+ T cells in tumor specimens from HIV patients $(69.6 \%)$ were less intense than that in the non-HIV patients $(93.1 \%)$ ".

Should be replaced with the following:

(Corrigendum) "The levels of infiltration and accumulation of CD4+ T cells in tumor specimens from HIV and non-HIV patients were similar in the all patient cohort. However, in the propensity-score matched cohort, CD4+ T cells should a significant difference between HIV and nonHIV patients".

In the "Results" section, the sentence on page 499 lines 2-4 is incorrect:
(Original) "Low level of infiltration of CD56+ cells in the tumor tissue was significantly associated with poor prognosis in both the HIV ( $p=0.0002)$ (Fig. 3e) and the non-HIV cohorts $(p=0.002)$ (Fig. 3f)".

Should be replaced with the following:

(Corrigendum) "Low level of infiltration of CD56+ cells in the tumor tissue was significantly associated with favorable prognosis in the HIV cohort $(p=0.0002)$ (Fig. 3e) but with poor prognosis in the non-HIV cohort $(p=0.002)$ (Fig. 3f)"'.

All these errors do not change the conclusion of the paper. The conclusion is supported by other figures in the paper, as well as the results described in the text. 